\title{
The Role of Non-formal Education in Empowering Women to Improve The Family Economy
}

\author{
Rulam Ahmadi \\ Universitas Islam Malang \\ rulam@unisma.ac.id
}

\begin{abstract}
This paper intends to explain the role of non-normal education in empowering women to improve the family economy. Empowerment is an approach in which women are provided with educational or training services so that they have a set of venture capital to improve their economic conditions. This research was conducted using qualitative research methods, namely describing the phenome of the implementation of women's empowerment through non-formal education to improve the family economy as developed by Pahlawan Ekonomi (PE) in the city of Surabaya. The implication of empowering women is the acquisition of a new set of knowledge, experiences, skills, and attitudes so that participants are able to apply them in their daily lives to increase their income. Economic activities in the family are generally the responsibility of the husband, but not all families are able to meet their needs if they only rely on their income from the husband. Wives (women) generally only receive what their husband's income is, even though women have the potential to participate in increasing family income. It is time for the participation of women (wives) in improving the family economy to be developed. Women do not only depend on their husband's economic income, but on how they also play a role in supporting the improvement of the family economy. Women's participation in increasing the family economy should start from empowering women through education or training that is suitable for their situation and condition. Education that is suitable for empowering women is integrated nonformal education, namely non-formal education whose content of learning is related to the problems or needs of the families of students, namely improving the family economy. The results of this study indicate that the participants of nonformal education (through education and training) experienced changes in their mental attitudes and awareness of the importance of women's involvement (wives) in family economic activities. They do not depend on their husbands anymore, and they attend training in economic skills, so that at the end of the activity they acquire a set of skills that can be used to open new businesses that support the family economy.
\end{abstract}

Keywords: Empowerment, Nonformal Education, Family Economy

$\begin{array}{ll}\text { Article History } & \text { Received : August } 7^{\text {th }} 2020 \\ & \text { Revision : October } 11^{\text {th }} 2020 \\ & \text { Publication : Dec } 30^{\text {th }} 2020\end{array}$




\section{INTRODUCTION}

This research article will describe the empowerment of women through non-formal educational activities in order to improve the family economy. Generally economic interests are the responsibility of the husband in the family, but in economic conditions that have not met the needs of the family then the woman (who in this paper is the wife) has great potential to participate in accelerating the welfare of the family economically.

Women in different countries tend to still be discriminated against. Women are exploited for various interests both in socio-economic, political, cultural and so on. As Kadam (2012) put it, "Women who are discriminated against and exploited are still seen all over the world". Women are made helpless and treated only to be male helpers and babysitters. These symptoms still occur in developing countries, including Indonesia.

Women in the history of Indonesian people's lives are seen and treated as "wingking" (Javanese) or "the back people". This means that the woman only takes care of the back affairs in the household, such as cooking, washing, parenting, and serving the husband. Men are seen as money-seekers and decision makers in the household, while women carry out male decisions. This view turns out to be detrimental to all parties both to the wife, the husband, including to the wider development.

Women have enormous potential that if developed optimally and empowered sustainably, it will contribute greatly to the improvement of the family economy as well as national development. As stated by Kadam, "Women play an important role in all the fields of development. Socially economically if she is strengthened then she will create wonders. Women contribute directly and indirectly for the economic development(Kadam, 2012). The statement asserted that the woman must be strengthened (her awareness and capacity) to contribute more to economic development. National economic development begins with the development of the family economy, where women have great potential to mambil part in it.

As long as the view on women is still negative, then women continue to be placed in a position of helplessness, defeat, or defeat. As a result, women cannot give their participation more and more broadly both in the family and in society, especially in terms of economic development. Helpless women do not have the opportunity to develop their talents and interests (abilities), their social interactions are very limited, can not participate in the decision-making process in issues related to their life problems in the family and community.

In line with the times, more and more Indonesian women are getting adequate education both through formal education and non-formal education. With this education, women gain new knowledge, skills, and attitudes that allow them to participate in development more broadly. Women not only work in kitchen affairs and 
serve husbands, but women should be able to act more broadly for family welfare and development success.

Education is one of the main capitals for women's empowerment. Education for women's empowerment is an education that suits the characteristics and needs of those who may develop new skills, knowledge, and attitudes. With education women will be able to be creative and innovative, as well as able to make changes and improve their lives, especially in increasing family income.

Education has three models: formal education, informal education, and non-formal education. The type of education suitable for the empowerment of women, especially women of the same age or school age but not possible to obtain education through school, is non-formal education. Non-formal education is more flexible age, length of learning, and content (material) learning so as to enable women to obtain education with materials that suit their needs, quickly, and can be applied in an immediate time to answer their urgent needs.

\section{METHOD}

This research uses qualitative research approach. This study emphasizes describing the phenomenon of an event, which in the context of this research is a phenomenon about "The Role of Non-formal Education in The Empowerment of Women to Improve Family Conomy". Qualitative research can be defined differently by different experts based on the understanding or literature it reads. Flick, Kardorff, and Steinke (2004) define qualitative research as following, "Qualitative research claims to describe life-worlds 'from the inside out', from the point of view of the people who participate. By so doing it seeks to contribute to a better understanding of social realities and to draw attention to processes, meaning patterns and structura lfeatures". This definition explains that qualitative research is to describe a phenomenon or peistiwa from the point of view of people participating in certain events (activities). The implementation in this study that this study describes the role of non-formal education in the eradication of women in the form of training in order to improve the family economy, namely participants who participated in the training.

This type of research is case study. Barry MacDonald and Rob Walker, 1975 in Bassey (1999) define case studies as follows, "Case-study is the examination of an instance in action". A case study is an laminate of an example of an action. In the context of this research, case studies are an laminate on one event or activity, namely about the role of nonfomal pendidian to empower women so that they can improve their family's economy. 


\section{RESULT AND DISCUSSIONS}

\section{Reasons for Women's Empowerment}

Women's empowerment is an effort to provide opportunities for women to be free from discrimination and exploitation, and free to develop their potential to contribute both to the interests of the family and society at large. Women have great potential to contribute to national development. Kadam (2012) stated,"Women play a very strategic role in the development of society in particular and development of economy in general. Woman is the leader planner of the family, the first trainer; supplier of labour and by playing focal role in the development of different sectors such as agriculture, industry, service, etc. and she contributes to the creation of an enlightened society. Women contribute directly or indirectly for economic development." The statement asserts that women play an important role in economic development through a variety of economic activities both services and goods. They can pursue their interests and abilities in agriculture, industry, handicrafts, education and training, and so on.

Another reason for the importance of women's empowerment is to fill their free time. Generally women in both urban and rural areas have a lot of free time. If their free time is not filled with various useful activities, then they can be affected and accustomed to doing activities that are detrimental to themselves and their families. Unemployed women tend to fill their free time with activities such as watching television, talking about other people's disgrace with others, playing games, and so on. If women's free time is used for training and entering the economy, then the benefits are enormous for their lives and development at large.

Increasing women's participation in development is another reason for the importance of women's empowerment. Women who have new knowledge, skills, and attitudes that can be obtained through the learning process (such as training) will make women more productive. With the increasing productivity of women, they have directly or indirectly given their participants in development. Productive women will encourage her to be more creative so that her productivity increases; it means that their participation is increasing. The impact on the family economy is increasing as a starting point for national economic growth.

Women's empowerment as a process of increasing human capital. During the 1960s interest in human capital contributions began to surface. His initial contribution, the emphasis was on the contribution ofhuman capital to individual living standards (income per person)and its attribution to aggregate well-being; then the emphasis shifted on its role as a contributor to aggregate economic growth(Savvides \& Stengos, 2009). Eknomi scientists such as Becker and Schultz initiallyreliedon physical capital,but since the 1960s they have shifted to the role of human capital in economic growth. Schultz narrowly identified human capital with investment in education by proposing a proposition that "An important increase in national income is an additional consequence 
of human capital stock (Schultz, 1960)." He argued that investment in education could account largely for the increase in per capita income in the United States. Another expert (Amend \& Herbst, 2008) also asserts that specific human capital directly increases the productivity of workers in the production process.

There are many definitions of women's empowerment and empowerment. Of the many definitions, the point is the same, namely the possibility of the community both individuals and groups to voice their concerns / needs, choose and determine alternative actions, perform actions according to their choice, and evaluate and obtain the results of their actions.

\section{The Role of Non-formal Education to Improve the Family Economy}

In the long history of economic development theories embraced by most economists about factors in economic growth provide a pressure point on the capital of money, meaning the more accumulated capital the greater the chance of economic growth. But the theory is quickly or later abandoned by the emergence of new studies both from the results of research and the results of discussions among economists and economic actors in the field. In the early 1960s it was a time when thinking began to shift to the role of human capital in economic growth.

The affirmation of the economists above is rational because in fact the "economic machine" is human. No matter how much physical capital, and as sophisticated as any technology owned by the company will not automatically increase the economy significantly. All that capital depends on who uses money and technology, i.e. people. Therefore, the level of knowledge, skills, and attitudes of the community (employees) is the main key to economic growth. This is where education plays an important role in providing new knowledge, skills and attitudes to society.

To meet the needs of households that are urgent and need skills that can be applied immediately and at the same time support income becomes another challenge. There are three types of education that are generally developed, namely formal education (school), non-formal education, and informal education. Putting choices against schools is impossible because it is long-term and educational material is very common. So in the context of this paper is a non-formal education as an alternative to empower women in order to increase the income (economy) of the family. Various developing countries nonformal education is used as the main alternative to provide skills to the community to improve the family economy as well as in the framework of poverty alleviation. Such as Bangladesh, India, Thailand and others have included non-formal education in the national development agenda, especially with regard to women's empowerment.

Education that should be given to women in the context of empowerment isbasic education. As stated by IDB, "Basic education is the bedrock upon which all human 
resource development is found. Basic education must be available to everyone for growth and development to be inclusive. Without this foundation, no society can develop effectively. Not only must education be universally accessible, it must also be good, relevant, and sustainable to equip citizens to improve society and to benefit from social and economic progress. " The statement affirms that basic education is a good, relevant, and sustainable equipment for women to improve themselves and for the advancement of the family economy. Thus, that basic education is a weapon for women to improve themselves and their economic progress.

\section{Integrated Non-formal Education in Women's Empowerment}

In general, non-formal education can be defined as educational activities that take place outside the school system (formal education). The purpose outside the school system is outside the rules that apply in schools. The school system is so strict that it is impossible for women who have settled down to get an education through formal education. The school also does not offer educational programs that can be achieved in the immediate term and can be completed immediately. Therefore the alternative is integrated non-formal education.

Integrated non-formal education means non-formal educational activities that in its implementation are combined with other dimensions of development, such as economic dimensions. Women's productivity improvement is determined in part by their new level of knowledge, skills, and attitudes which are all the result of education. To obtain a variety of educational education (various abilities) requires a considerable cost. So education and the economy have a reciprocal or mutually affecting relationship.

Women who will get an education, which in the context of this paper are women who are not or are unlikely to get an education through formal education, then nonformal education is an effective option. Women who need education to improve performance in their present world of work or to enter the world of work immediately then non-formal education can meet these needs. Non-formal education with flexible characteristics can serve the education of women who have the need to implement educational outcomes immediately.

Integrated nonfromal education not only integrates non-formal education with economics, but also integrates with other dimensions whose orientation is on increasing women's incomes. This is because the concept of empowerment itself is concerned with many dimensions to realizeempowered women. Empowerment also concerns sociocultural, political, and security.

The socio-cultural dimension is related to work motivation. Women who are lazy to learn and lazy to work, they will never experience a change in their lives. Relaxing habits and accepting the fate of her life, including relying on others (husbands) will not 
encourage them to improve her life. It also includes the reluctance or embarrassment of interacting with others as an obstacle for women to exchange experiences and work with others, so that they become isolated or excluded. Therefore, in order to empower women non-formal education plays an important role to provide knowledge, experience, and motivation to women about the importance of the spirit (motivation) of learning and work, independent living, and the willingness to interact and cooperate with others (other individuals or groups). All of these are intended so that women are able to enter a "new world" to improve the economy of their homes.

The political dimension means that these women need to gain new knowledge, understanding, and attitudes about the importance of participating in decision-making processes related to the issues (needs) of their lives. Women should be courageous and have the opportunity to voice their indispensable needs in order to make decisions about planned programs for themselves. Included in the process of determining the nonformal education plan to be implemented and they are part of the program. One of the characteristics of non-formal education is the flexible curriculum(material), meaning that the curriculum in non-formal education is tailored to the learning needs of learners, unlike in schools where the curriculum is made rigid and uniform.

\section{The Role of Integrated Non-Formal Education in Women's Empowerment}

The main key to women's empowerment is education. With education, women will have new knowledge, skills, and attitudes that allow them to adapt to changes and developments related to the economic condition of the family. One of the important roles of education in women's empowerment is to enable them to have a set of knowledge and skills to improve the family economy.

There are three types of education, namely formal education (school), informal education, and non-formal education. Non-formal education is a type of education relevant to the empowerment of women in order to improve the family economy. Nonformal education is an education that is organized outside the school system (rules). The rules of play in non-formal education are more flexible than formal education (school). while the school is rigid. Therefore, an education suitable for the empowerment of women for economic improvement is non-formal education.

Non-formal education has high flexibility, especially in its curriculum. Curriculum in non-formal education is compiled based on the results of identification of learning needs. Therefore, learning (training) in non-formal education begins with the identification of the learning needs of prospective learners. Those who are ready to learn have learning needs that are expected to be overcome by applying learning outcomes. 
Integrated non-formal education for women begins with an analysis of learning needs, namely the need for the necessary knowledge and skills, which in this case is the need to increase family income. With the skills gained through non-formal education, women can create a certain product, then market it so that it earns income. With her efforts, women's income helps support the improvement of the family economy so that the family is more prosperous.

\section{Discussion}

Non-formal education is an education that takes place outside the formal education system. Kamil said,"Non-formal education with various attributes and names or other terms, either called mass education, adult education, lifelong education, learning society, out-of-school education, social education etc. is an organized and systematic activity organized outside the formal education sub-system (Kamil, 2009). This education provides educational services that are impossible to obtain in school, such as practical skills that can be applied immediately in order to meet urgent needs.

Non-formal education as an educational institution that takes place outside the formal education system (school) plays an important role in the empowerment of women, especially in order to provide them with knowledge, new attitudes, and productive skills. With this non-formal education, women have a set of practical skills that can be used for self-advancement, especially for improving the family economy. As stated by Dwi Sulstiani that, "Non-formal education as one of the approaches in development, will be able to make people more advanced, qualified, valued in the social eyes, and have high competitiveness, and will ultimately be able to improve the degree of social life of the community and canincrease work productivity personally and nationally for the betterment of the nation and state" (Sulistiani, 2019).

Implementation of education (learning) Non-formal education begins from the problems or life needs of learners, namely women. Every family has a variety of problems, but in general that all families have economic interests where the whole family wants the economy adequate to meet the needs of daily life. In order for education to be effective for the fulfillment of the interests of family ecoomi, education must be carried out based on the analysis of the needs or interests of learners (women). Sulistiani said, "Non-formal education for women should be centered on women with a point of decline from women, implemented by women and its benefits for women's empowerment. So "Process" will show a real action that must be done gradually to be able to change the condition of a weak society, both in terms of knowledge, attitude, and practice towards the mastery of knowledge, attitude of conscious behavior and good skills so that people can be empowered to improve their standard of living from a previous life" (Sulistiani, 2019). Unlike formal education which is based on the national 
curriculum, formal education has a curriculum and materials that have local principles even more specifically based on the learning needs of learners.

Women empowerment through non-formal education provides results in the form of changes and improvement of self-quality. The main thing is a change in mental attitudes that all depend on the husband in economic affairs to be independent and participate in terms of improving the family economy. In addition, the female learners obtained a set of knowledge, attitudes, and skills that can be used as the basic capital to open a business that is able to provide additional family income. By studying the group also the women can exchange their thoughts and experiences so that their insights and thoughts become broader that allow women to be more advanced in a sustainable manner.

\section{CONCLUSION}

Non-formal education contributes to women's empowerment in the form of improving self-quality. Women's empowerment through a series of non-formal educational activities designed and implemented based on the needs of women allows them to gain the ability in order to open or develop their economic business so as to contribute to improving the family economy.

The implementation of non-formal education for women's empowerment results in the form of obtaining a new set of knowledge, attitudes, and skills. With that ability, women can make productive efforts that allow them to provide support in improving the family economy. In order for non-formal education to be effective for women's empowerment, it must consider the needs or interests of women who are learners in non-formal education through a series of education and training.

\section{REFERENCES}

ADB. (2008). Education and Skills. Strategies for Accelerated Development in Asia and The Pacific. Metro Manila, Philippines: Asian Development Bank.

Amend, Elke \& Patrick Herbst. (2008). Labor Market Pooling and Human Capital Investment Decisions. IAB Discussion Paper. German: The Research Institute of The German Federal Employment Agency.

Bassey, Michael. (1999). Case Study Research in Educational Settings. Philadelphia: Open University Press.

Flick, Uwe, Ernst Von Kardorff And Ines Steinke. (2004). A Companion to Qualitative Research. London: SAGE Publications. 
Kadam, Ravi N. (2012). Empowerment of Women in India, An Attempt to to Fill the Gender Gap. International Journal of Scientific and Research Publications, Volume 2, Issue 6, June 2012.

Savvides, Andreas and Thanasis Stengos. (2009). Human Capital and Economic Growth. California: Stanford Economics And Finance, An Imprint of Stanford University Press Stanford.

Schultz, T. W. (1960). "Capital Formation by Education.” Journal of Political Economy 68:571-583.

Sulistiani, Dewi. (2019) 'Peran Pendidikan Non Formal Berbasis Sosial Ekonomi dalam Organisasi Sosial Preman Super di Malang Raya', Jurnal Pendidikan Ilmu Pengetahuan Sosial, Vol. 5, No. 2, Juni 2019, Halaman:13-28. P-ISSN:2355 8245; E-ISSN:2614 - 5480. 